\title{
LONGITUDINAL MAGNETORESISTANCE OF UNIAXIALLY DEFORMED THIN POLYCRYSTALLINE Bi FILMS
}

\author{
R. Tolutis \\ Semiconductor Physics Institute, A. Goštauto 11, LT-01108 Vilnius, Lithuania \\ E-mail: tolutis@pfi.lt
}

Received 23 October 2006

\begin{abstract}
The large longitudinal magnetoresistance (MR) of high quality uniaxially deformed $1.5 \mu$ m thick polycrystalline bismuth films deposited in vacuum on non-crystalline substrate and annealed at critical temperatures was investigated. The experimental results are interpreted on the basis of polycrystalline Bi thin film model. The data suggest that in tellurium doped Bi films the influence of uniaxial deformation on MR can be up to $400 \%$. It was found that strain and compression cause a considerably different dependence of MR on magnetic field, which is explained in terms of electron intervalley repopulation in polycrystalline film crystallites.
\end{abstract}

Keywords: bismuth, thin films, magnetoresistance, deformation

PACS: $68.03 . F g, 73.50 . J t$

\section{Introduction}

$\mathrm{Bi}$ is a typical semimetal with the overlap of the valence and conduction bands of about $30 \mathrm{meV}$. The low carrier concentration together with a small effective mass and a long mean free path has made $\mathrm{Bi}$ a material for quantum transport investigations. The highly anisotropic Fermi surface and large carrier mobility has made Bi important for applications.

Strong anisotropy of the electrical conductivity of bulk $\mathrm{Bi}$ and $\mathrm{Bi}_{1-x} \mathrm{Sb}_{x}$ single crystals under strain in the direction of the binary $\mathbf{C}_{2}$ axis has been investigated by Shubnikov-de Haas effect measurements at liquid helium temperature in [1] and by magnetoplasma waves at $77 \mathrm{~K}$ in [2]. It was shown that the anisotropy and orientation of the hole "ellipsoid" and the electron "ellipsoids" did not change in the wide range of deformation. However, Lifshitz electron phase transitions and topological alterations of the Fermi surface $3 e+1 h \rightarrow 2 e+1 h, 3 e \rightarrow 1 e, 3 e \rightarrow 2 e$ are observed. The strain in direction of $\mathbf{C}_{2}$ axis causes the transitions of electrons from valleys $L_{2}$ and $L_{3}$ to valley $L_{1}$ with high anisotropy of electron mobility. The electrical piezoeffect caused by the deformation-induced anisotropy of electron mobility in the semiconducting $\mathrm{Bi}_{1-x} \mathrm{Sb}_{x}$ was measured by the crossed induction coil technique [3].
The application of bulk single crystals is limited by their low mechanical strength and the complicated technology required to prepare single-crystal devices. Many workers have studied the galvanomagnetic effects of the bismuth films extensively. The anisotropy of electrical conductivity and electrical piezoeffect due to anisotropy was found and in uniaxially deformed polycrystalline Bi films consisting of crystallites from 200 to $400 \mathrm{~nm}$ in size [4]. It was demonstrated that thin $\mathrm{Bi}$ and $\mathrm{Bi}-\mathrm{Sb}$ films could be used for the development of deformation and magnetic field sensors $[5,6]$. High quality single-crystal (epitaxial) Bi films exhibit large magnetoresistance (MR) effects at low and room temperatures $[5,7,8]$. Only very recently high quality Bi thin films have been produced using the method of evaporation of Bi onto a non-crystalline dielectric substrate in high vacuum with a post-annealing process at critical temperatures $T_{\mathrm{c}}$ close to the film melting temperature $[9,10]$. The large magnetoressistance of such films is associated with high anisotropy of $L$-electron mobility in large high quality crystallites.

In this paper, we report on investigations of large longitudinal magnetoresistance in the uniaxially deformed high quality thin polycrystalline Bi films prepared at critical temperatures. 


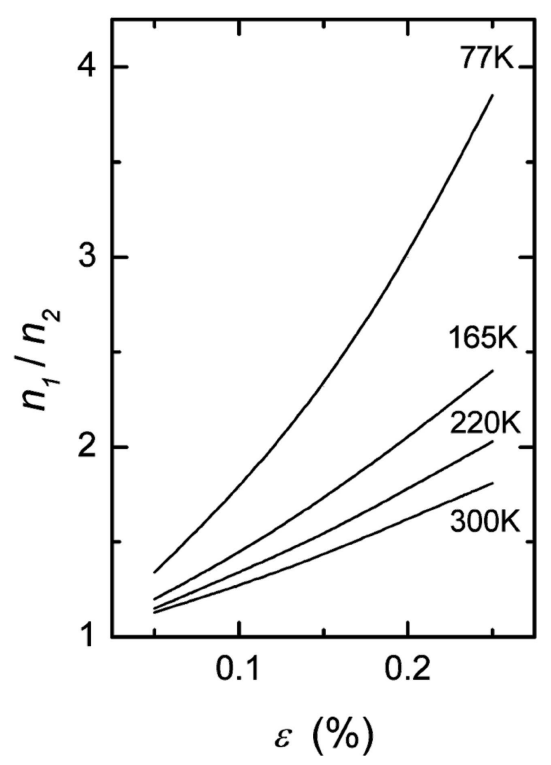

Fig. 1. Dependence of the ratio of electron concentrations $n_{1}$ and $n_{2}$ in the two $L$-type valleys of $\mathrm{Bi}$ on deformation $+\varepsilon_{x x}$ in $\mathbf{C}_{2}$ direction at different temperatures.

\section{Longitudinal resistivity of deformed polycrystalline $n$-Bi films}

The longitudinal resistivity $\rho_{11}$ and MR of polycrystalline $\mathrm{Bi}$ films was calculated using the model proposed in Refs. [4, 10,11], where the film is represented by a structure consisting of the microcrystallites having trigonal surfaces parallel to film surface. The mi- crocrystallites are turned with respect to each other in a plane parallel to film surface. The state of the thin film in the substrate plane can be treated as quasi-isotropic. In a uniaxially deformed $\mathrm{Bi}$ and $\mathrm{Bi}_{1-x} \mathrm{Sb}_{x}$ the energetic position of the three electron $L$-valleys (compared to the bottom of the valence zone at the $T$-point of the Brillouin zone) depends on the direction and the magnitude of deformation. The strain deformation $\left(+\varepsilon_{x x}\right)$ in the direction of the binary $\mathbf{C}_{2}$ axis or compressive deformation $\left(-\varepsilon_{x x}\right)$ in bisectric $\mathbf{C}_{1}$ axis causes a transition of electrons from valleys $L_{2}$ and $L_{3}$ to valley $L_{1}$. Compression in $\mathbf{C}_{2}$ axis or strain in $\mathbf{C}_{1}$ axis induces a transfer of electrons from valley $L_{1}$ to valleys $L_{2}$ and $L_{3}$. Theoretical calculations of intervalley repopulation and the mobility of $L$-electrons in $\mathrm{Bi}$ and $\mathrm{Bi}_{1-x} \mathrm{Sb}_{x}$ microcrystallites [12] are based on the McClure equation [13]. The energy spectrum of the electrons described by this equation is non-parabolic and the isoenergetic surfaces are nonellipsoidal. Typical curves of the ratio of electron concentrations $n_{1}$ and $n_{2}$ in the two $L$-type valleys of $\mathrm{Bi}$ at different temperatures as a function of deformation $+\varepsilon_{x x}$ in $\mathbf{C}_{2}$ direction, calculated using the relaxation time approximation, are shown in Fig. 1. As it is easily predictable, the repopulation of electrons is much higher at lower temperatures, but even at $300 \mathrm{~K}$ there is a considerable part of extra electrons remaining in the higher-energy valley $L_{1}$ (about $50 \%$ in the lower-

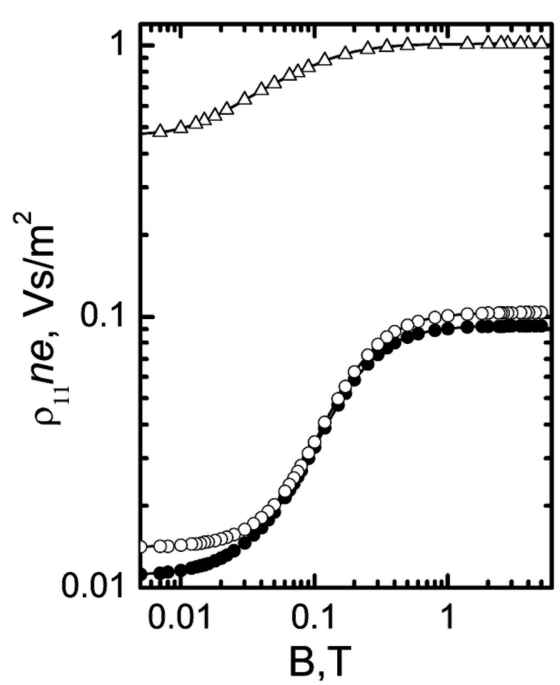

(a)

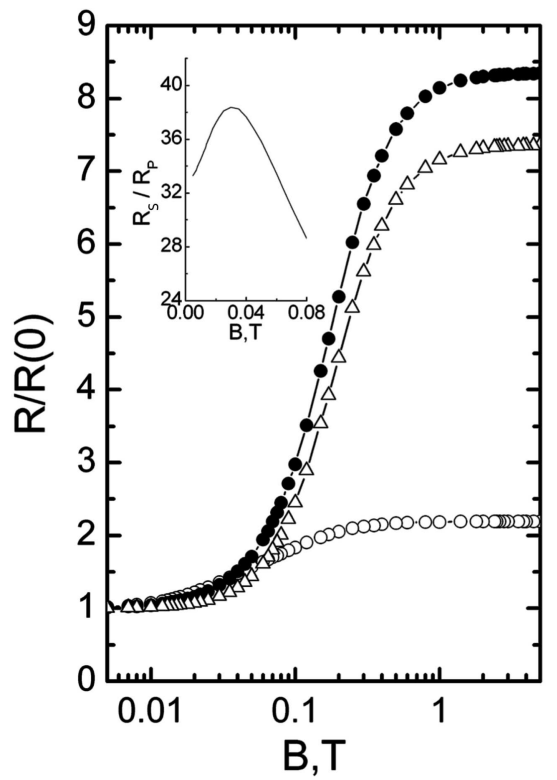

(b)

Fig. 2. (a) Calculated dependences of the longitudinal resistivity of bismuth film $\rho_{11}$, normalized to the carrier concentration $n$ and charge $e$, on magnetic field $B$ for the compression $P$ (open triangles) and strain $S$ (open circles) at $\pm \varepsilon_{x x}=0.25 \%$ and at $\varepsilon_{x x}=0$ (full circles); (b) calculated dependence of ratio $R(B) / R(B=0)$ on $B$ for Bi film: for the strain $S$ (open triangles) and compression $P$ (open circles) at $\pm \varepsilon_{x x}=0.25 \%$ and at $\varepsilon_{x x}=0$ (full circles). The inset in (b) shows the dependence of ratio of R(B) at $S$ and $P\left( \pm \varepsilon_{x x}=0.25 \%\right)$ on $B$. 
energy valley $L_{2}$ at $+\varepsilon_{x x}=0.25 \%$ ). On the other hand, this means that the repopulation of electrons into one or two valleys is far from complete in the temperature range considered. It should be noted that Shubnikovde Haas effect measurements at liquid helium temperature show that in Bi crystals the one-valley semiconductor is realized for deformation $+\varepsilon_{x x}>0.18 \%$ [1].

The electrical piezoeffect measurements in tellurium-doped semiconducting $n$-Bi-Sb crystals at liquid nitrogen temperature show that under strain in the direction of the binary $\mathbf{C}_{2}$ axis for $+\varepsilon_{x x}>0.1 \%$ the electron repopulation rate $n_{1} /(3 n)$ is $>0.8$. Here $n_{1}$ is electron concentration in valley $L_{1}$ and $3 n$ is electron concentration in valleys $L_{1}, L_{2}$, and $L_{3}$ [3].

The electrical resistivity $\rho_{11}$ and longitudinal MR calculations for polycrystalline Bi films were made in the classically strong non-quantizing magnetic fields under uniaxial strain $S$ or compression $P$ in the film plane in direction parallel to dc current. We suppose that for deformation $+\varepsilon_{x x}>0.25 \%$ the electron repopulation rate $n_{1} /(3 n)>0.8$. The values of mobility $\mu_{1}=59, \mu_{2}=1.12, \mu_{3}=32.7, \mu_{4}=-3.8$ (in units of $10^{4} \mathrm{~cm}^{2} \mathrm{~V}^{-1} \mathrm{~s}^{-1}$ ) for electrons in the vicinity of $L$-points of $\mathrm{Bi}$ at liquid nitrogen temperature and electron concentration $3 n=5.24 \cdot 10^{17} \mathrm{~cm}^{-3}$ were used [14]. Here the labels 1, 2, and 3 mark the binary axis, bisectric axis, and trigonal axis, respectively. We used the crystallite resistivity tensor $\rho$ elements obtained from mobility-field product calculations (the formulae are given in the Appendix).

A comparison of calculated values of the longitudinal resistivity of deformed bismuth film $\rho_{11}$ as a function of magnetic field $\mathbf{B}$ applied parallel to the film plane is shown in Fig. 2. We suppose that the conductivity is determined by $L$-electrons (e.g. in Bi film doped with $\mathrm{Te}$ ) and deformation is parallel to $\mathbf{B}$. As can be seen from Fig. 2(a), the difference in calculated $\rho_{11}$ values for strain and compression is large. The magnetic field $B$ decreases the influence of the deformation on $\rho_{11}$.

The longitudinal MR was calculated by using the ratio $R(B) / R(B=0)$, where $R(B)$ and $R(B=0)$ are film resistances at a certain magnetic field and zero magnetic field, respectively. Figure 2(b) shows the MR ratio $R(B) / R(B=0)$ versus $B$ dependences for Bi films under strain and compressive deformation $\left( \pm \varepsilon_{x x}=0.25 \%\right)$. As can be seen, the compression at higher magnetic fields, where $\omega_{\mathrm{c}} \tau \gg 1$ (here $\omega_{\mathrm{c}}$ and $\tau$ are the cyclotron frequency and relaxation time of charge carriers), significantly decrease MR (up to 400\%). The longitudinal MR ratio in compressed Bi films increases as $B$ increases and tends towards saturation when $B>0.3 \mathrm{~T}$. The tendencies to saturation in the strained and undeformed Bi films show up at $B>$ $0.8 \mathrm{~T}$. The magnitude of MR in the compressed Bi films is larger than in strained ones at $\omega_{\mathrm{c}} \tau \approx 1$ and the ratio $\rho_{11}(S) / \rho_{11}(P)$ shows a maximum (see the inset of Fig. 2(b)). Here $\rho_{11}(S)$ and $\rho_{11}(P)$ are film resistivities at strain and compression, respectively.

The longitudinal resistivity of polycrystalline bismuth film $\rho_{11}$ is caused by resistivities of two groups of microcrystallites: with $\mathbf{B}$ approximately in the direction of the bisectric axis $\mathbf{C}_{1}$ and with $\mathbf{B}$ approximately in the direction of the binary axis $\mathbf{C}_{2}$. The depending on $B$ magnitudes and behaviours of $\rho_{11}$ and longitudinal MR of such microcrystallites are very different. The strain or the compression in the $\mathbf{C}_{2}$ direction induces a transfer of electrons between the mentioned groups and causes considerable changes of $\rho_{11}$ and longitudinal MR. Figure 2(b) shows a nonsymmetric change of MR under the strain and compression deformation. This is due to the different resistivity and anisotropy of the electron mobility in each of the two groups of deformed microcrystallites.

\section{Longitudinal resistivity in deformed undoped Bi films}

The conductivity in undoped (pure) Bi films is determined by the concentration and mobility of $L$-electrons and $T$-holes. The $T$-holes in substrate plane have a larger effective mass than the $L$-electrons. Considering the transport properties in undoped Bi films in nonquantizing magnetic fields, the total magnetoconductivity tensor can be found by summing the partial contributions of $L$-electrons and $T$-holes.

Figure 3 shows the calculated longitudinal MR magnetic field dependences in deformed at $\pm \varepsilon_{x x}=0.25 \%$ and undeformed Bi film. As can be seen, at higher magnetic fields, in the range where $\omega_{\mathrm{c}} \tau \gg 1$, holes decrease MR from 8.3 (Fig. 2(b)) down to 2.5. The Fermi surface of $T$-holes is an ellipsoid of revolution with its major axis along the trigonal axis. For this reason, the conductivity caused by $T$-holes in substrate plane noticeably reduces the anisotropy of the film determined by $L$-electrons and reduces MR [11]. On the other hand, the influence of holes on MR in compressed $\mathrm{Bi}$ film is small. This could be explained by assuming that the longitudinal resistivity of compressed bismuth film is caused by the group of microcrystallites with lower anisotropy. 


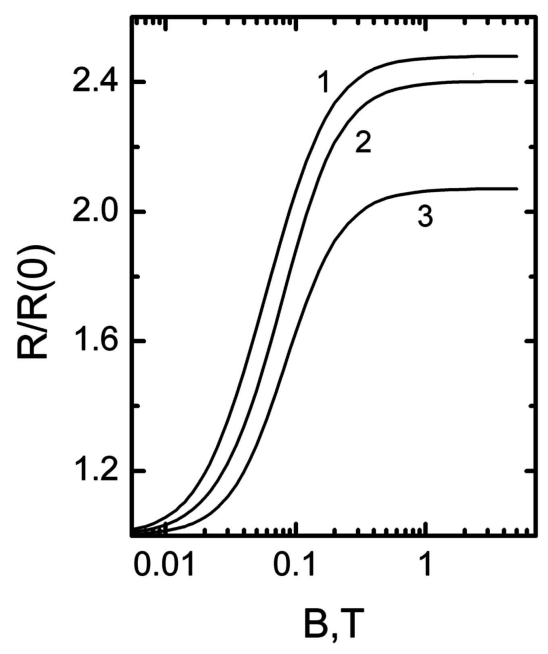

Fig. 3. Calculated dependence of ratio $R(B) / R(B=0)$ on $B$ for undoped Bi film: undeformed (line 1$)$, strained (line 2$)$, compressed (line 3).

\section{Experimental}

Bismuth thin films for longitudinal MR investigations were prepared by thermal vacuum evaporation onto substrates made from Corning 7059 glass. The deposition of $99.999 \%$ pure Bi was performed using a Mo boat at a pressure of $10^{-6}$ torr and an evaporation rate of $\sim 1.5 \mathrm{~nm} / \mathrm{s}$. The distance between the Bi source and the substrate was about $10 \mathrm{~cm}$. The films were plated at substrate temperature of $390 \mathrm{~K}$. The film thickness $d$ was $1.5 \mu \mathrm{m}$. The annealing process was performed in vacuum at critical temperatures $T_{\mathrm{c}}$ near the film melting temperature. In this case, small melted crystallites create favourable conditions for the growth of larger crystallites having a higher quality and more ordered crystalline structure. The size of the crystallites ranged from 50 to $200 \mu \mathrm{m}$. Films having an extra-high quality structure and very large MR were obtained on Corning glass substrates at critical temperatures $T_{\mathrm{c}}$ [6]. Samples were in the shape of $2 \mathrm{~mm}$ wide strips. The electrical contacts were made from thin $\mathrm{Ag}$ films, which were deposited onto the Bi film using suitable masks. Finally, $\mathrm{Cu}$ leads were attached to the $\mathrm{Ag}$ contact areas by means of $\mathrm{Ag}$ based conducting epoxy. The longitudinal MR was measured in a dc magnetic field of inductance up to $2.5 \mathrm{~T}$. The experimental arrangement for investigating axial strain or compression deformation was the same as in [6].

A comparison of calculated and experimental data on the longitudinal MR ratio $R(B) / R(B=0)$ of the strained and compressed undoped Bi films annealed at critical temperatures $T_{\mathrm{C}}$ is shown in Fig. 4.

The longitudinal MR ratio of the Bi film annealed as usual at temperatures $T_{\mathrm{A}}<T_{\mathrm{c}}$ (grain size from 3 to

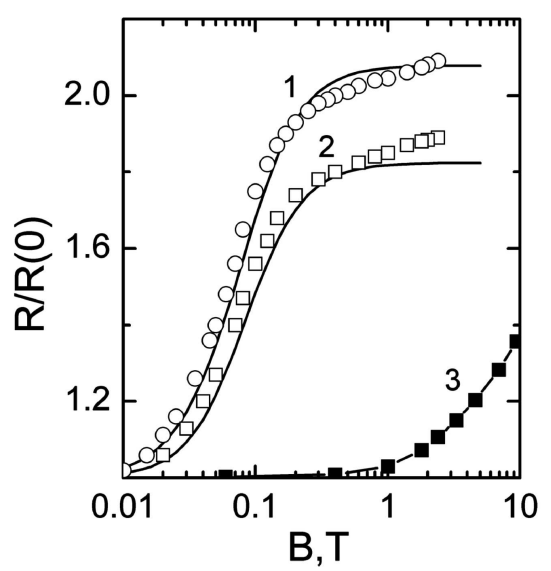

Fig. 4. Magnetic field dependences of ratio $R(B) / R(B=0)$ for Bi film. Calculations for strained (line 1 ) and compressed (line 2) high quality film structure. Present experimental results for strained (empty circles) and compressed (empty squares) high quality film structure. Experimental data for undeformed polycrystalline film (full squares) [15]. The magnetoresistance was measured at $77 \mathrm{~K}$.

$6 \mu \mathrm{m})$ [15] is shown by curve 3 in Fig. 4 . It can be seen that the abrupt increase in the film resistance in weaker magnetic fields starts at magnetic fields many times larger than that for films annealed at critical temperatures $T_{\mathrm{c}}$. This could be explained by much greater $L$-electron and hole mobility in the annealed at critical temperatures $\mathrm{Bi}$ films. In annealed at $T_{\mathrm{c}} \mathrm{Bi}$ film the scattering at the intercrystallite boundaries is weak. A good agreement between the behaviour of MR versus the magnetic field for suitably annealed undeformed $\mathrm{Bi}$ films and those calculated within the bulk polycrystalline model was obtained for non-quantizing magnetic fields. The good fits between the experimental and calculated values of MR was obtained using an additional scalar relaxation time, which reduced the $L$-electron and $T$-hole mobilities by $30 \%$. This could be explained by assuming that rather isotropic extra scattering channels exist, such as scattering from the film surface or from other imperfections [9]. On the other hand, there is a difference between the experimental and calculated MR values for the strained and compressed Bi films. This could be explained by supposing that in strained and compressed at deformation $\pm \varepsilon_{x x}=0.25 \%$ polycrystalline Bi film the electron repopulation rate $n_{1} /(3 n)$ is lower than 0.8 in the temperature range considered.

\section{Appendix}

From Bi crystal symmetry and topology of electron and hole Fermi surfaces it follows that in the substrate plane the Bi film microcrystallites can be divided into 
two approximately equal groups [4]. The microcrystallites of group $a$ have crystallographic axis $\mathbf{C}_{1}$ and those of group $b$ have crystallographic axis $\mathbf{C}_{2}$ orientated in the substrate plane parallel to the current direction. The trigonal axis $\mathbf{C}_{3}$ of the majority of microcrystallites is inclined to the substrate surface normal at angles smaller than $5^{\circ}$. The prepared Bi film thickness is equal to the microcrystallite thickness. The resistivity $\rho$ of these films can be represented as a series of resistances $\rho_{a} l_{1}^{-1}, \rho_{b} l_{1}^{-1}, \rho_{\mathrm{Gb}} l_{2}^{-1}$. Thus one can write

$$
\rho(B)=\frac{l_{1} \rho_{a}(B)+l_{1} \rho_{b}(B)}{2 l_{1}+l_{2}}+\frac{l_{2} \rho_{\mathrm{Gb}}}{2 l_{1}+l_{2}},
$$

where $\rho_{\mathrm{Gb}}$ is the resistivity of the grain boundary. If the microcrystallite size $l_{1}$ is much greater than the grain boundary thickness $l_{2}$, then

$$
\rho(B)=\frac{\rho_{a}(B)+\rho_{b}(B)}{2}+\frac{l_{2} \rho_{\mathrm{Gb}}}{2 l_{1}} .
$$

Since $\rho_{\mathrm{Gb}}$ is independent of magnetic field, the MR is independent of the term that contains $\rho_{\mathrm{Gb}}$.

The longitudinal resistivity ( $\mathbf{B}$ is in the film plane and parallel to the current) then is

$$
\rho_{L}(B)=\frac{\left[\rho_{L}^{a}(B)\right]^{-1}+\left[\rho_{L}^{b}(B)\right]^{-1}}{2},
$$

where

$$
\begin{aligned}
\rho_{L}^{a}= & n e\left(\frac{\mu_{1}+\Delta_{e} B^{2}}{1+\Delta_{e} B^{2} / \mu_{1}}\right. \\
& \left.+\frac{\mu_{1}+3 \mu_{2}+4 \Delta_{e} B^{2}}{2+0.5\left(3 \mu_{1} \mu_{3}+\Delta_{e} / \mu_{1}\right) B^{2}}\right) \\
& +p e \frac{\nu_{1}+\Delta_{h} B^{2}}{1+\nu_{1} \nu_{3} B^{2}}
\end{aligned}
$$

and

$$
\begin{aligned}
\rho_{L}^{b}= & n e\left(\frac{\mu_{2}+\Delta_{e} B^{2}}{1+\mu_{1} \mu_{3}}\right. \\
& \left.+\frac{3 \mu_{1}+\mu_{2}+4 \Delta_{e} B^{2}}{2+0.5\left(\mu_{1} \mu_{3}+3 \Delta_{e} / \mu_{1}\right) B^{2}}\right) \\
& +p e \frac{\nu_{1}+\Delta_{h} B^{2}}{1+\nu_{1} \nu_{3} B^{2}} .
\end{aligned}
$$

In these expressions, the symbol $\sigma_{L}$ represents longitudinal conductivity of $a$ and $b$ microcrystallites. The symbols $\Delta_{e}, \mu_{j}$ and $\Delta_{h}, \nu_{j}$ denote the determinants and elements of the mobility tensors for $L$-electrons and $T$-holes, respectively. The densities of $L$-electrons
$(3 n)$ and $T$-holes $(p)$ are assumed to be equal, where $3 n=n_{1}+n_{2}$.

\section{References}

[1] N.B. Brandt, V.A. Kulbachinskii, N.Ya. Minina, and V.D. Shirokikh, The band structure alterations and threefold transitions in uniaxial strained $\mathrm{Bi}_{1-x} \mathrm{Sb}_{x}$ alloys, Zh. Eksp. Teor. Fiz. [Sov. Phys. JETP] 78, 18301843 (1980) [in Russian].

[2] R. Požèra and R. Tolutis, Anisotropy of electrical conductivity in uniaxial strained Bi-Sb films, Fiz. Tverd. Tela (Leningrad) [Sov. Phys. Solid State] 23, 33663371 (1981).

[3] R. Tolutis, Electrical piezoeffect in semicon ducting $\mathrm{Bi}-\mathrm{Sb}$ alloys due to anisotropy of electron mobility Phys. Status Solidi B 185, 439-446 (1994).

[4] R. Tolutis and V.Tolutis, Anisotropy of electrical conductivity in uniaxial deformed thin Bi films, Phys. Status Solidi A 157, 65-73 (1996).

[5] F.Y. Yang, Kai Liu, Kimin Hong, D.H. Reich, P.C. Searson, and C.L. Chien, Large magnetoresistance of electrodeposited single-crystal bismuth thin films, Science 284, 1335-1337 (1999).

[6] R. Tolutis and V. Tolutis, Electrical piezoeffect in thin polycrystalline Bi films due to shear deformation, Lithuanian J. Phys. 37, 155-160 (1997).

[7] P.M. Vereecken, L. Sun, P.C. Searson, M. Tanase, D.H. Reich, and C.H. Chien, Magnetotransport properties of bismuth films on p-GaAs, J. Appl. Phys. 88, 6529-6535 (2000).

[8] Sunglae Cho, Yunki Kim, L.J. Olafsen, I. Vurgaftman, A.J. Freeman, G.K.L. Wong, J.R. Meyer, C.A. Hofman, and J.B. Ketterson, Large magnetoresistance in post-annealed polycrystalline and epitaxial $\mathrm{Bi}$ thin films, J. Magn. Magn. Mater. 239, 201-203 (2002).

[9] R.A. Tolutis and S. Balevičius, A study of large magnetoresistance of thin polycrystalline Bi films annealed at critical temperature, Phys. Status Solidi A 203, 600607 (2006).

[10] R. Tolutis, V. Tolutis, and S. Balevičius, Transport properties and structure of thin Bi films prepared at critical substrate and annealing temperatures, Lithuanian J. Phys. 45, 53-57 (2005).

[11] R. Tolutis, Anisotropic magnetoresistance of thin polycrystalline $\mathrm{Bi}_{1-x} \mathrm{Sb}_{x}$ films, Lithuanian J. Phys. 43, 353-359(2003).

[12] A. Sutkus and R. Tolutis, The influence of electron scattering features on the anisotropy of electrical conductivity in deformed thin $\mathrm{Bi}$ and $\mathrm{Bi}_{1-x} \mathrm{Sb}_{x}$ films, Phys. Status Solidi A 173, 417-424 (1999).

[13] J.W. McClure and K.H. Choi, Energy band model and properties of electrons in bismuth, Solid State Commun. 21, 1015-1018 (1977).

[14] I.F.I. Mikhail, O.P. Hansen, and H. Nilsen, Diffusion thermolectric power of bismuth in non-quantising 
magnetic fields. Pseudo-parabolic model, J. Phys. C 13, 1697-1713 (1980).

[15] R. Tolutis, V. Tolutis, J. Novickij, and S. Balevičius,
Negative magnetoresistance of polycrystalline thin $\mathrm{Bi}_{1-x} \mathrm{Sb}_{x}$ alloy films in quantizing magnetic fields, Semicond. Sci. Technol. 18, 430-433(2003).

\title{
KRYPTINGAI DEFORMUOTU PLONU POLIKRISTALINIŲ Bi SLUOKSNIŲ IŠILGINĖ MAGNETOVARŽA
}

\author{
R. Tolutis \\ Puslaidininkiu fizikos institutas, Vilnius, Lietuva
}

\section{Santrauka}

Naujos Bi sluoksnių fizikinių savybių panaudojimo perspektyvos skatina pastovų domèjimąsi ir jų plonais sluoksniais, kurių pagrindinis privalumas - labai paprasta ir pigi ju gamybos technologija ir didelis mechaninis atsparumas. Stipriuose magnetiniuose laukuose tirta kryptingai deformuotų aukštos kokybès plonų polikristalinių sluoksnių didelè išilginè magnetovarža. Sluoksniai buvo pagaminti vakuuminio garinimo ant amorfinių padèklų būdu, po to juos atkaitinant krizès temperatūroje, artimoje sluoksnio tirpimo temperatūrai. Tų sluoksnių kristalitų skersmuo gali pasiekti kelis šimtus mikronų. Didelè magnetovarža žymi gerą tokių sluoksnių kokybę. Tinkamiausio atkaitinimo režimu gautų sluoksnių savybẻs, esant toms pačioms sąlygoms, yra artimos monokristalinių sluoksnių savybėms. Sluoksniai buvo deformuojami iki 0,25\%, juos tem-
\end{abstract}

piant ar spaudžiant padèklo plokštumoje išilgai magnetinio lauko krypties.

Deformuotų polikristalinių sluoksnių išilginè magnetovarža buvo skaičiuota, naudojant patobulintą polikristalinio sluoksnio modeli ir tenzoriaus sandų lygtis. Nustatyta, kad didelis (iki 400\%) išilginès magnetovaržos pokytis turètų būti stebimas sluoksnį suspaudus, kai sluoksnio elektrini laidumą sukelia $L$ elektronai. Tai galètų būti stebima Bi sluoksniuose, papildytuose donorine priemaiša. Sluoksnius tempiant magnetovaržos pokytis nežymus. Švariame $\mathrm{Bi}$, kai puslaidininkinio sluoksnio elektrinį laidumą sukelia $L$ elektronai ir $T$ skylès; $T$ skylès žymiai sumažina magnetovaržą, kartu ir deformacijos poveiki. Tai patvirtina ir eksperimento rezultatai. 